Peter Topalovic, Gail Krantzberg (Eds.)

Responsible Care ${ }^{\circledR}$ 


\section{Also of Interest}

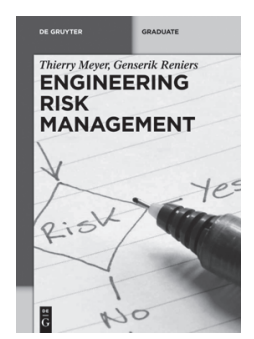

Thierry Meyer, Genserik Reniers

Engineering Risk Management, 2013

ISBN 978-3-11-028515-4, e-ISBN 978-3-11-028516-1

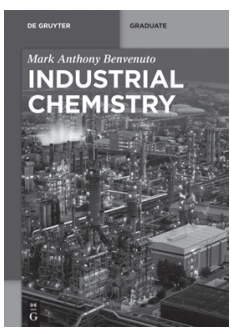

Mark Anthony Benvenuto

Industrial Chemistry, 2013

ISBN 978-3-11-029589-4, e-ISBN 978-3-11-029590-0

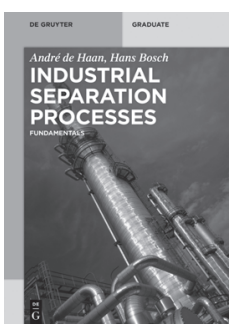

André de Haan, Hans Bosch

Industrial Separation Process, 2013

ISBN 978-3-11-030669-9, e-ISBN 978-3-11-030672-9

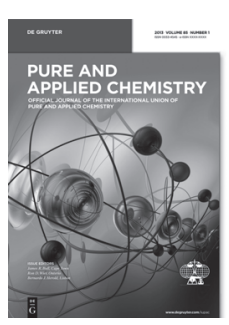

International Union of Pure and Applied Chemistry (IUPAC)

Pure and Applied Chemistry

ISSN 0033-4545, e-ISSN 1365-3075

\section{CHEMISTRY}

International Union of Pure and Applied Chemistry (IUPAC)

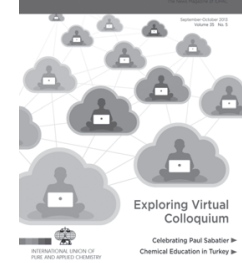

Chemistry International

ISSN 0193-6484, e-ISSN 1365-2192 
Peter Topalovic, Gail Krantzberg (Eds.)

Responsible Care ${ }^{\circledR}$

A Case Study

Edited by Peter Topalovic and Gail Krantzberg

Published in cooperation with the International Union of Pure and Applied Chemistry (IUPAC)

\section{DE GRUYTER}




\section{Editors}

Peter Topalovic, M.Eng.

Dr. Gail Krantzberg

School of Engineering Practice

McMaster University

Ctr. of Engineering \& Public Policy

1280 Main Street West

School of Engineering Practice

McMaster University

Ctr. of Engineering \& Public Policy

Hamilton, ON, L8S 4L7

1280 Main Street West

Canada

Hamilton, ON, L8S 4L7

e-mail: topalopj@mcmaster.ca

Canada

e-mail: krantz@mcmaster.ca

ISBN 978-3-11-034292-5

e-ISBN 978-3-11-034316-8

Set-ISBN 978-3-11-034317-5

\section{Library of Congress Cataloging-in-Publication Data}

A CIP catalog record for this book has been applied for at the Library of Congress.

\section{Bibliographic information published by the Deutsche Nationalbibliothek}

The Deutsche Nationalbibliothek lists this publication in the Deutsche Nationalbibliografie; detailed bibliographic data are available in the Internet at http://dnb.dnb.de.

C 2014 Walter de Gruyter GmbH, Berlin/Boston

Typesetting: Compuscript Ltd.

Printing and Binding: Hubert \& Co. GmbH \& Co. KG, Göttingen

Cover image: Thinkstock/iStock

$\infty$ Printed on acid-free paper

Printed in Germany

www.degruyter.com 